\title{
Critical practice and the public pedagogy of environmental and conservation media
}

\author{
John Blewitt \\ Director of Lifelong Learning \\ Aston University, UK \\ j.d.blewitt@aston.ac.uk
}

\begin{abstract}
This article addresses the reluctance of mainstream corporate and commercial media to critically address major environmental and conservation issues. The resulting public pedagogy largely reproduces the neo liberal ideology informing much conservation practice and discourse. Nonetheless, the media retains an unrealised critical educative potential that needs to be drawn upon by critical media practitioners and educators. To do this educators need to be cognizant of the phenomenological experience of spectatorship, the aesthetic form and relational contexts of media consumption, production and informal learning. Referring to the work of Vivian Sobchack, Henry Giroux, Pierre Bourdieu and Gilles Deleuze, the article argues that if critical practitioner-educators apply an analytic framework informed by critical realism, counter hegemonic elements found within corporate and independent media productions and conservation initiatives may be rearticulated and re-presented in a more positive manner. For this to occur, critical media practitioners-educators need to recognise that feasible political and normative alternatives are both available and practically possible. The article ends by discussing some relatively recent non-fiction productions that express a commonality between human and non human animals and so form the basis of a critical environmental education-media practice.
\end{abstract}

Keywords: media, public, pedagogy, critical, environment, conservation

\section{Introduction}

It is now almost a truism that we learn as much, if not more, outside formal learning environments than within them. Media analysts, theorists and critics have explored media effects, agenda setting, cultivation, para-social interaction, edutainment and the pedagogic implications of non-fiction and fiction productions. Educationalists have written extensively about both old and new media literacy, the educative value of TV programming and the re-emergence of a McLuhanesque concern with how new media technologies may be reshaping our culture and our minds (McLuhan, 1964; Lum, 2006). Neil Postman (1986) and Henry Giroux (2001) have questioned the media's potential to offer either critical or progressive learning opportunities to 
audiences although for some commentators they underestimate the active processes of interpretation and re-articulation occurring among individual media consumers and interpretative communities. Public education and communication campaigns have used film, photography, television and now the internet for many years with considerable success. Even so, some critics have been insisting for many years that image based media deflect attention away from the more serious or deeper logocentric arguments (Postman, 1986; Mander, 2002; Winn, 2002). However, as Mitchell (2002) notes, image based communication is by no means one dimensional or lacking in analytical import. All media are actually mixed media employing varying ratios of sense impressions and sign-types.

Conservationists, environmental activists and critical educators are often innovative and creative users of image based media. They can communicate clear messages that may nurture public concern and stimulate further learning and sometimes effective action (Author, 2010). Their field of reference is vast but in this paper environmental and conservation filmmaking will refer to broadly those productions that address the frequently negative ecological impacts of human socio-economic development whereas wildlife and natural history filmaking is understood as taking animal behaviour, ecological adaptation and evolution as its primary concern. Such media practice constitutes a form of public pedagogy but importantly rigorous critique does not generally characterise mainstream/corporate environmental and conservation media productions although many do have an overt educative remit (Cottle, 2004). Conservation and environmental scientists frequently advise on, feature in, write and/or present natural history television series, 'specials' and documentary films. Rarely though will production companies commission evaluative research on whether learning has actually taken place.

The BBC's long running Natural World series and National Geographic documentaries offer ample evidence of this. Indeed, some natural history producers, such as Steve Nichols (2010) maker of Drain the Oceans (2009) for National Geographic view their programme making as a form of public outreach for science but admits, "even though the most you can hope for is that they [the audience] come away with a few facts or factoids" rendering the educative influence of natural history programming on audiences a perennial interest of filmmakers and conservation 
practitioners. For George McGavin (2010), a former Oxford academic and presenter of the BBC documentary series Lost Land of Volcanoes, films are made to inspire but it is hard to know what learning actually takes place although anecdotally he can cite a number of individuals who became conservation scientists through being inspired by TV programmes. Similarly, environmental filmmaker and professor of Environmental Filmmaking at the American University in Washington DC Chris Palmer (2010) told aspiring filmmakers at the 2010 Wildscreen Film Festival that television executives are predominantly concerned with basic audience ratings and ratings remain the major influence on what gets funded and distributed'. These views simply illustrate common knowledge within the industry, that is, critical environmental or conservation programmes are frequently viewed by major commissioning editors as unattractive and undesirable commercial propositions (Bouse, 2000; Chris, 2006; Author, 2010; 2011).

When making a pitch to commissioning editors at festivals or trade fairs new filmmakers are frequently advised to avoid the 'c-word' (conservation). It is often something to be avoided when making a pitch as audiences frequently avoid, distance themselves or selectively deny uncomfortable, disagreeable or inconvenient truths (Zerubavel, 1997; Norgaard, 2006). However, there is some evidence that television natural history does have some positive impact on attitudes and behaviours (Chris, 2002 \& 2006; Holbert et al, 2003). Fortner and Lyon's (1985) study of a Jacques Cousteau television special noted that audiences were clearly receptive to new information but although producers were successful in altering viewer attitudes in their preferred direction, that is against the culling of harp seals, attitudinal changes were short lived. Interestingly, Cousteau combined an "ecologistic" with a "moralistic" attitude and the success or otherwise of his documentaries, often directly conceived as public and pedagogic interventions, were largely dependent on the pre-existing knowledge, values and life experience of his audiences (Shaheen, 1987). Fiction films can have a positive pro environmental influence on audiences too. A study of the Hollywood narrative film Medicine Man (1992) concluded that viewers "became significantly more favourable in their attitudes toward forest preservation" (Bahk, 2011:8-9). Largely through immersion in story and character, viewers become highly receptive to filmic techniques leading the author to conclude (Bahk, 2011: 10), 
It is plausible that narrative films with their suspenseful presentations of events involving human characters could facilitate constructive learning in "education for sustainability" through eliciting intense emotional, empathic reactions to environmental issues portrayed.

\section{More Than a Representation and Less than a Thing}

Just as all media are mixed media, images are more than just pictures. They impact upon thought and perhaps constituting a shock to, or even a form of, thought 'communicating vibrations to the cortex' (Deleuze, 1989: 157). For the Soviet filmmaker Sergei Eisenstein, montage is a dynamic process creating a product or 'intellectual cinema' that has as its correlate 'sensory thought', its own emotional intelligence as well as conscious concepts. Additionally, as Deleuze explains, the figure-image, say a person or an animal, may embody an affective charge creating a new or intensifying an existing shock. Film theorist Vivian Sobchack (1992; 2004), drawing on the existential phenomenology of Maurice Merleau-Ponty, refers to images as having an affective materiality arguing that a pre-reflective bodily responsiveness to films is a fundamental characteristic of the viewing experience. She writes (Sobchack, 2004: 63-64).

... we do not experience any movie only through our eyes. We see and comprehend and feel films with our entire bodily being, informed by the full history and carnal knowledge of our acculturated sensorium. Normatively, however, the easy givenness of things for us to see at the movies and vision's overarching mastery and comprehension of its objects and its historically hierarchical sway over our other senses tend to occlude our awareness of our body's other ways of taking up and making meaning of the world - and it's representation.

With the powerful sensory impact of IMAX 2-D, and particularly 3-D, 'viewer' experiences have become increasingly immersive and totalising. Science Centre's, Aquaria and Natural History Museums frequently promote large format digital 3-D environmental, natural history and wildlife films as a stunning sense experiences.

In his article on immersion cinema Tim Recuber (2007) argues that 3-D IMAX projection on screens that may be up to the equivalent of eight stories and, 
combined with the effects of auditorium architecture including stadium style seating and digital surround sound, offers audiences a lived experience that amplifies the first-person perspective to a new level of simulated participation. He writes (2007: 321),
With powerful base notes and explosions providing a visceral rumbling, curved screens enveloping one's peripheral vision; and increasingly, 3-D images literally jumping off of those screens, contemporary film exhibition represents a bodily discipline, a technological interface between narrative and reality that blurs many distinctions between lived bodies and screen space.

For Recuber (2007) such visceral participation is not necessarily the same as meaningful audience interaction but recognises that such immersion cinema has the largely unrealised potential to become a 'thirdspace' allowing for openness, flexibility multiplicity and far more agency or embodied interactivity than are afforded by other media technologies. Keith Beattie notes in a complementary fashion that the size of the image, relatively slower rate of cutting and a higher incidence of (often aerial) travelling shots than usually experienced in conventional 2-D movies, functions as a mode of cognition or a technologically-enhanced revelatory 'showing'. The result is the production 'of a documentary display which radically enhances the basic premise of documentary as a mediation of the real world capable of generating knowledge and understanding' (Beattie, 2008: 150). Thus, films such as Ocean Wonderland (d. Mantello, 2003) and Dolphins and Whales - Tribes of the Ocean (d. Mantello, 2008) show marine animals moving effortlessly from positive (behind the screen plane) to negative space (in front of the screen plane) seemingly making real the marketing invitation to join the creatures in their natural adventures. Thus, the spectator experience becomes one of 'presence', that is a subjective perception in which the viewer largely or wholly fails to acknowledge that current experience is being essentially produced or induced by a technological apparatus (Lombard \& Ditton, 1997). As Noel Carroll (2003) writes, emotions help manage and direct attention enabling individuals to organise the details of their experience into significant gestalts, values patterns and cultural meanings.

In a narrative fiction film, and some documentary forms, the spectator's emotional responses are organised through each scene, sequence, narrative event, plot line, 
character and an array of visual and aural effects articulated according to prefocussed generic codes, that is aesthetic techniques intended to elicit a specific response or interpretation in the viewer. In other words, to be effective the criterially prefocussed, or encoded, film text must become aligned with the emotive focus of the audience and, to ensure that this is so, the filmmaker must invite the audience to invest in the film's issues, characters, stories and experiences. All this requires educators and researchers to seek more holistic and connective understandings of how the media may, and do, shape social cognition, affective knowing, environmental perception, contribute positively to formal and informal learning and realise the potential of large screen immersive cinema to be a 'thirdspace' (Recuber, 2007; Apley, 2008; Griffiths, 2008).

Theoretical research on audience's apprehension of still and moving image texts have incorporated recent findings from neuroscience such as Torben Grodal's (2006) PECMA flow model incorporating perception, emotion, cognition and motor action. In Embodied Visions Grodal (2009) argues that films provide scenarios for living through vital aspects of human experience. Using evolutionary theory, Grodel shows that films often reflect human beings' universal embodied nature and may help offer new resolutions to these problems. Similarly, Anna Munster (2006) explores the interaction of science and art showing how digital culture is reconfiguring bodily experience. Digital artists, in particular, often place the human body in a sensory physical interaction with technology. New artefacts are being created from a range of different physical and virtual ingredients coming together in a process that Deleuze termed 'folding'. The mediascape is simultaneously converging and diverging, one being imprinted on the other - small screen 2-D, massive screen 3-D. Film texts are interacting with other media texts and being transformed through their differential conditions and contexts of consumption, use and re-production. New media technologies such as the internet, ipod or iphone offer social, as oppose to individual, models of cognition and creativity although the form technological interaction may take remains resolutely one of isolation. Thus, I may view the trailer for Wild Ocean on my iPhone listening to the sound through earphones but in a social public space. I may interact with other viewers, animal lovers or conservationists, in a variety of different spatial and temporal locations diachronically or synchronously. The trailer becomes more than a text and the tweet or blog 
becomes more than a message as informal e- or mobile learning platforms become increasingly baroque in their affects, contingencies and differential affordances. All this enables the user to generate a multiplicity applications, repurposing and reversioning.

For Deleuze (1995: 149) "the brain's organised like a rhizome", seemingly a botanic metaphor referring to a mass of laterally growing roots of shoots, and the cinema "screen can work as a brain". With the advent of new media technologies and with an emerging micro-politics of new media culture, the cinema and the smart phone are themselves enfolded in a new constellation of mediated images and learning. This suggests that the rhizome, as a conceptual tool, connects with other artistic, social or everyday fields and, in so doing, metamorphoses into other figurations that are not purely representational (Colombat, 1991). The cinematic, and by extension the new media image, as Rodowick (2009) notes in the Afterimages of Gilles Deleuze, is an image of thought and a new way of thinking thought, of undertaking practical critique. New media ecology is changing human social relationships and our relationships to the 'natural' environment and to the ever declining numbers of non domesticated animals (Watson, 2011). In her discussion of digital technologies media texts and environmental awareness Ursula Heise (2003: p.71) writes that if the digital environment becomes conflated with that of the physical, including its actual and imagined wildlife then,

The lack created by diminishing nature and disappearing species (...) may come to be filled in the cultural imagination of computer literate societies by alternative life forms on the global Web.

The gap will be filled by digital image archives and electronic zoos made possible, perhaps necessary, by the onward momentum of capitalist economic development, world trade, and technological innovation and business opportunism. Criticality is not the same as expression or communication and the learning process needs to distinguish between them. This presents serious and important critical challenges to environmental educators, conservationists and media practitioners. Learning, creativity and expression often involve resisting, of linking signs, events, life and vitalism to wider social and ethical responsibilities. Deleuze writes (1995: 131), 
Different modes of expression may have different creative possibilities but they are all related insofar as they must counter the introduction of a cultural space of markets and conformity - that is, a space of "producing for the market" - together.

Classic blue chip TV series such as BBC's Planet Earth (2006) or National Geographic's Great Migrations (2010) presents the audience with a montage of attractions, an exhibition of awe and wonderment, a media exercise in what may be termed 'scopophilic biophilia' - a love of looking at nature. There is movement animals react to circumstances and seek to overcome them instinctively. As Gilles Deleuze writes (1986), the relations between images are key and when perception becomes purely optical the image(s) relate most closely to the action. When they become thought rather than seen, they become legible rather than simply visible creating a pedagogy of the image. For Deleuze (1989), the movement-image and the time-image have the capacity to create fluid movements and temporalities mobilising and inducing particular logics of affect towards heterogeneous political ends. As Sobchack (2004) argues, documentary space is constituted as the perceived conjunction of the viewer's lifeworld and the space of the film text activated and subjectively judged, or inscribed, as ethical for it is a world that has been called into being, and shared, by the visual responsiveness and responsibility of the viewer and filmmaker combined. Film and the moving image, in this context, is therefore a mediator by which learners may express and constitute themselves and by which things, that may otherwise remain hidden, come into view. This will be developed in a later section.

\section{Critical Realism}

The public pedagogy of environmental and conservation media constitutes part of the wider socio-cultural environment. It may either disclose or foreclose various conditions and possibilities for learning, agency and cultural practice. Critical practice, which is at least in part also constituted through material and symbolic relationships, links capabilities to the abilities of groups and individuals to undertake action. Consequently, knowledge and desire, being inextricably connected to forms of technologically mediated modes of address, need to become a central focus for 
critical educators. The radical educator Henry Giroux (2000: 354) argues that "public pedagogy is defined through its performative functions, its ongoing work of mediation and its attentiveness to the interconnections and struggles that take place over knowledge, language, spatial relations, and history". In this context, teaching and researching public pedagogy is part of a critical practice that aims to uncover lived relations of power, their discourses, representations, structures of affect, networks of diffusion and socio-economic conditions and contexts of production. Giroux states (2004) that the ideological dominance of neo-liberalism over the last twenty years has meant that the educational import of culture has undermined some important foundations for critical agency. However, certain models of higher education remain "one of the few sites where students can be educated to understand, engage critically and transform those dominant spheres of public pedagogy that are largely shaping their beliefs and sense of agency" (Giroux, 2004: 498) but higher education itself is becoming increasingly dominated by the logic of market. As Pierre Bourdieu (Bourdieu and Wacquant, 1992) reminds us, academics, particularly social scientists, tend to be located near the dominated pole of the field of power.

Critical educators, of which sustainability practitioners ought to be included, need to embrace a pedagogy of intervention that relates everyday experiences to the wider material circumstances of their generation. Such a politicised critical pedagogy is not about indoctrination but rather an exploration emphasising norms of social responsibility, democracy and ecological justice. It requires the development of analytical skills, an ethics and an articulation of concepts and percepts that recognising culture to be a domineering force but seeing learning as potentially emancipatory. Thus, a critical pedagogic practice should not devalue or ignore the heuristic possibilities afforded by various hegemonic cultural forms as sites of exploration, contestation, resistance and transformative learning (Ellsworth, 2005; Savage, 2009). However, in many instances this will be dependent on educators researching and being able to draw out, and on, difference. The critical theorist Nikolas Kompridis (2005: 332) writes,

Critique does not aim at truth but at the reflective disclosure of possibility, the 'truth' or 'correctness' of which can be verified, to the extent that possibility can be 'verified', only by the addressees of critique and only retrospectively, in the course of time. In other words, critique is unavoidably 'utopian'; not in the 
sense that it depends on the availability of a determinate utopia, but in the sense that it depends on the openness and receptivity of the future to utopian thought - to the genuine possibility that things might be otherwise than they are.

For Denzin (2003), when critical imagination is framed as an interventionist ideology it is necessarily hopeful of change, improvement and challenging of hopelessness and quietism. Hope is ethical, moral and peaceful. It confronts cynicism and the belief that change is either impossible or too costly. Critical researchers and educators therefore live, or perform, these 'utopian' ethics through their practice and many have done so by co-opting the educational force of popular culture and everyday lived experience (Tisdell \& Thompson, 2007; Wright \& Sandlin, 2009). Critical pedagogic practice acknowledges environmental and conservation media as being part of a complex constellation of contexts each with their own imprinted values and ideological politics, debts and relationships to the wider socio-economic and political fields. The public pedagogy of commercially produced wildlife and natural history films generally purvey a view of the natural world that is actually far from natural with its ideological occlusions rendering the images of nature pristine, unspoiled, pure, sublime and basically false (Foale \& Macintyre, 2005). The same economic and financial processes that drive the destructive palm oil industry, agri business, factory farming and dragnet fishing deforestation, species extinction, economic development also drive the media industry - the market, profit, commodification, capital accumulation and so on (Harvey,1996; 2006). Sharon Beder (2006) has meticulously documented, global corporations have, over the last thirty years, successfully established an hegemonic supremacy in all areas of social, economic, environmental and political policy making. Environmental and wildlife film festivals often include trade fairs exhibiting new technologies and provide an interface between art and finance, business and conservation, text and context.

What is invariably absent in the public pedagogy of mainstream wildlife and natural history films, including the DVD 'extras', is this politico-economic production context but it is this very context that needs to become a key focus of critical research and pedagogic engagement. To lift the ideological veil from these media productions, researchers and educators must work within a framework of philosophical realism (Bhaskar, 2008: Soper, 1995) where 'nature' refers to the deep structures, powers 
and processes that operate constantly within the physical world conditioning the ways humans may, or can, intervene in, reshape, exploit, understand or interact with the environment. What we see are basically surface appearances, empirically observable natures like the tailored countryside, the clearcut forest, palm oil plantation, game reserve or luxury ecotourist resort. Normative standpoints are embedded in the ideological representations of these appearances. So, being able to critique these standpoints becomes a stage towards conceiving, identifying, examining and realising feasible 'realistic' alternatives (Sayer, 2000). For geographers like Noel Castree (2003; 2008a; 2008b), Marxist normative standpoints and alternatives are the most convincing. Although elements of nature are privatised and commodified, nature as a whole is not. Complex ecosystems such as the Indonesian rainforests have been split and commodified to create legally definable and tradable properties.

Following the financial crises of 2008 , there has been a systemic deepening of the operational space of advanced capitalism in the global South and North (Sassen, 2010). For centuries $C O 2$ has been simply dumped into the atmosphere.

Atmospheric pollution and climate change can be ascribed to market failure and the metabolic rift between capitalist accumulation and the Earth's natural ecologies (Benton, 1989; Foster, Clark \& York, 2010). All commodities are ultimately monetised and commensurable with any other type of good - the Indonesian rainforest and the Discovery Channel documentary on that disappearing forest. Nature is itself 'produced' (Smith, 2010) as a means to the end of capitalist economic growth. Human beings, plant seeds and chickens are elements of a commodification process that conceals the entwined processes of labour exploitation and ecological degradation. Ecotourism, carbon trading permits and the very concept of "ecosystem services" are aspects of this produced, commodified nature which, apart from harming 'the natural world', invariably disempowers local human and non human communities.

\section{Public Pedagogy and Critical Practice}


For a critical media and environmental education practice to assert itself, the educator seeks to combine a range of cross disciplinary analytical skills, eco-political and media literacies and knowledge(s) that will inform the selection, presentation, production and dissection of specific media texts, contexts and ecologies. The methodological criteria informing the discussion of the media texts and interventions below has as its starting point one recognising that human and non human animals have co-evolved and are biologically, socially and ethically interdependent. This is clearly the case with Jacques Cousteau's films and books which, although may be fading from public memory, do also offer explicit and powerful critiques of capitalist market forces and the uncontrolled actions of large corporations. A number of them such as The Warm Blooded Sea: Mammals of the Deep, Mediterranean: Cradle or Coffin from The Odyssey (1978) series and his final book, The Human, the Orchid and the Octopus, present a clearly oppositional perspective. He writes (Cousteau and Schiefelbein, 2007: p.159),

The depleted Third World waters, the fish sold for swine feed, the squandering of unprofitable fish - all point to the fact that we deplete world waters not in the quest for food, but in the quest of profits.

Rachel Carson, although no revolutionary, famously wrote a treatise that was clearly treated as dangerous by the large corporate interests threatened when the effects of nature commodification became too apparent. The PBS American Experience documentary Rachel Carson's Silent Spring (1993) made this plain offering critical educators an opportunity to review the chemical corporations' concerted efforts to undermine a series of public education and environmental justice campaigns. Writing in 1962 Rachel Carson (1999: p29) informs her readers in a prescient pre-echo of many of today's GM debates,

There is still very limited awareness of the nature of the threat [of chemical pesticides]. This is an era of specialists, each of whom sees his own problem and is unaware of or intolerant of the larger frame into which it fits. It is also an era dominated by the industry, in which the right to make a dollar at whatever cost is seldom challenged.

For Igoe, Neves and Brockington (2010), conservation and capitalism are shaping both the protection of nature and sustainable development industry according to neo- 
liberal market logics and the ideology of economic growth and capital accumulation. Luxury ecotourism resorts define themselves as private sector, profit driven companies and are frequently the unstated locations for respected natural history and wildlife films (Christophers, 2006; Duffy, 2010). Indeed, as Brockington, Duffy \& Igoe (2008) have shown the conservation and tourist industries invariably work together to produce the best possible spectacle for their customers and viewers. Together with their associated merchandising both are primarily consumptive experiences involving resource extraction, alienation and commodity fetishisation. An episode in Blink Production's Extraordinary Animals series (2007) for Channel Five and BBC World Wide featured the Thai elephant Hong who with a number of other elephants 'earn their living' by entertaining tourists. Hong's special talent is art and the programme concentrates on this seemingly bizarre curiosity. The episode offers a keen insight into eco-tourism and tangentially into the cultural heritage of the Thai's relationship to the elephant. Most importantly, it demonstrates a respect for these non human creatures derived in part from dignity, spiritual associations and their earlier crude physical exploitation clearly evident in the narrator's early allusion to elephants as 'living tractors' employed by the logging companies in the years preceding logging's ban in 1989. As Duffy and Moore (2010) write in their study of elephant back tourism in Thailand and Botswana the tourist industry has provided alternative employment for elephants and their mahouts and in Thailand, thanks to the god Ganesha, elephants are seen more than a base commercial enterprise. They have intrinsic worth and neo-liberal approaches to nature have inadvertently served to reinvent some traditional practices. Critical educators can draw upon and rearticulate these survivals or retrievals to show that even within existing hegemonic fields there are seeds for change and contestation. In 2008 the owner of a tourist enterprise Elephant Life Experience organised an elephant fashion show featuring clothes with patterns taken from elephant paintings to celebrate National Elephant Day. The show was designed to draw attention to elephant conservation, the Art by Elephants Foundation and the artificial insemination programme organised jointly by the privately owned Maesa Camp and the Elephant Hospital at the Thai Elephant Conservation Centre. The event reached television newsrooms and YouTube.

There are films and media initiatives that offer alternative perspectives that are philosophically more profound. Kalpavriksha (2000), written and directed by Nina 
Subramani and produced by the Indian conservation filmmaker Mike Pandey for UNESCO, emphasizes the importance of traditional ecological knowledge by focusing on the medicinal use of plants by the Irula tribe of Tamilnadu, the Kani tribe of Karela, and other peoples across India. These traditional remedies have been used for over three thousand years but the destruction of plants and the attendant local wisdom is now imminent because of economic development, habitat destruction and the patenting of commercially significant plant products by international drugs companies. Using a gentle aesthetic and an authoritative female voice-over, Kalpavriksha demonstrates the dependence of human culture on natural ecosystems by comparing of the lifeworlds of indigenous, "ecosystem peoples", with those of contemporary urban "omnivores" who devour the produce of the whole biosphere (Gadgil and Guha, 1995). Similarly, Japan's NHK public television network has produced a series of Satoyama documentaries exploring traditional ways in which Japanese people have lived in harmony with the natural world showing how human culture can be attuned to the needs and lives of non human creatures, particularly birds and fish, in a commercially non exploitative manner. The BBC acquired Satoyama: Japan's Secret Garden (1999) and Satoyama: Japan's Secret Watergarden (2004) following the series winning the Grand Prix at the 28th International Wildlife Film Festival in 2005. The Natural History Unit re-edited them into one 50 minute programme narrated by David Attenborough with the title Japan's Secret Water Gardens and was broadcast for the first time as part of the Natural World series in 2006.

Finally, the South African media company WildEarth TV and its subsidiary organisations including safari.tv have developed an internet based virtual ecotourism business producing recorded presenter-led programmes and live feeds in both 2-D and 3-D. With a special 'app' it is possible to watch a 3-D safari on an iPhone. Whereas traditional tourism relies on increasing numbers of actual visitors to maintain profitability and growth which in turn further stresses the environment, in theory with virtual tourism, where there is just one vehicle and one tourist/camera, there can be any number of virtual internet or television tourists. WildEarth TV's explicit focus on sustainability and ethics ensures that it will remain local and of genuine economic benefit to local people who have so often in the past been displaced by the ecotourism industry (Duffy, 2010). As the subsidiary companies 
reach profitability, the intention is that both the local communities and land owners will become equity partners allowing them to share in the revenues resulting from this global media orientated conservation business (Wallington, 2010). In this case, new media production ecologies are integrally connected to conservation action and informal environmental education within a commercial framework. If successful, it could reshape the very meaning and reality of 'eco-tourism'.

\section{Green}

Patrick Rouxel's Green (2009), a self-financed 48 minute film about the terrifying destruction of the Indonesian rainforests and the consequent extermination of the orang-utan in order to produce palm oil on an industrial scale, offers critical educators a valuable opportunity to address and research a whole range textual and contextual matters. In Green audiences are invited, through its various aesthetic and narrative codes, to understand the situation emotionally by being sutured into the psychic devastation, helplessness and physical suffering that has been wrought on a single individual/animal. Green posits the unfolding of time above that of motion or action. The opening shot is of an orang-utan imprisoned within a holdall dumped in the back of a pickup truck. Only the head is free as it bounces in sympathy to the severe bumps and jolts of the vehicle as it swiftly traverses the rough road. In this single shot the image includes the before and the after bringing together the conditions of a new rather than a present time-image or thought. As the narrative unfolds, it takes as its object the perceptions, feelings and reactions of the orangutan 'Green' to her desolate environment, to her 'hospital bed' attached and to her drips while incomprehensibly searching her memories of times past. She lies still, she ignores her food, she holds on to the wrist of her 'nurse', she looks at the camera lens and into the spectator's eyes and in this image the spectator is invited to 'feel her pain'. The film is almost a direct transposing of Deleuze (1989: 155) when he writes,

It is under these conditions of the time-image that the same transformation involves the cinema of fiction and the cinema of reality and blurs their differences; in the same movement, descriptions become pure, purely optical and sound, narrations falsifying and stories and simulations. The whole cinema becomes a free, indirect discourse operating in reality. 
The audience is presented with a filmic situation that cannot advance through reactions or actions, that is neither animate or inanimate, but which nonetheless offers a new way of understanding and resisting. Green's time-images (Deleuze,1989) are an indicator of something else, of a different ordering and transformation. Cognitive and emotional understanding, empathy and critical questioning are evoked in the spectator/learner through a juxtaposition of sounds and images inviting deep meditation on the suffering of a sentient creature, someone genetically very close to ourselves, a non-human person, who has rights, on economic growth, capital accumulation, consumer materialism and the ideology of sustainable development. Images of Neste Oil tankers, through their resonant association with earlier sequences depicting environmental and wildlife destruction, undermine the credibility and efficacy of WWF's Roundtable on Sustainable Palm Oil Production and the concept of biodiesel as a green fuel (Greenpeace, 2007). Consumerist seductions are destabilised by a montage sequence of everyday products, behaviours and advertising that feels as hollow as it is immoral because the world we see and responsible for is the world we have created.

Thus, Green works in the way the film maker intended because, as Carroll (2003: 86) notes, "the audience's faculties of cognition and judgement are brought into play in the process of eliciting an emotional response". Thus, documentary interventions like Green offers a visual and aural space through which the viewer may start to critique anthropocentric percepts. As Deleuze (1995) writes, the point of something is the measure of a statement's truth because what is being seen or experienced "connects any point to any other point, and its traits are not necessarily linked to traits of the same nature; it brings into play very different regimes of signs, and even nonsign states" (Deleuze and Guattari, 2004: 23). Thus, the public pedagogy of Green cannot be thought from the inside but must be conceived as a challenge emanating from the outside that is folded in. Consumer materialism and car culture is imprinted on a montage of desolation where a small troop of orang-utans hold on to life as desperately as they hold on to, and fall from, a single leafless tree. The past and the future is seen in this image too and as Herzog (2000) explains, the image becomes a complex provocation to thought possibly transcending the representational by exploring the interstices between memory and perception thereby introducing the viewer to new feelings, concepts, images of thought and 
orientations of oneself in thought. Green is also an important tool in the campaign to protect the habitats and lives of the orangutans. It is freely available as a download on www.grethemovie.com and so can be screened in its entirety, forwarded via social network media applications, recut for specific educational or campaigning activities and viewed on various fixed or mobile devices. Philosophically, it visually articulates this non reductionist naturalism, this commonality between human and non-human beings. There is no dialogue, no voiceover, no interviews and apart from those in a short song extract, only a single word heard - 'Green' - plaintively uttered by the dying orang-utan's carer. The (sound) images therefore serve as palpable shocks to sensory thought. This point is aptly summed up in a collective email I received during the writing of this article,

I'm sending you a link to a film that deserves to be watched. It's about 50 minutes long.

Because of what happens to her (and the profound effect she has had on me) I feel I owe it to the main/only character to do as much as I can to ensure her life was not in vain.

For those of you with children please encourage your children to watch it with you. I hope you will acknowledge that I rarely send emails of this type and, therefore, please understand that this is a bit special.

With love and determination

Caroline $\mathrm{x}$

PS. Perhaps you might like to tell other people about it.

As Benton (1993) argues this commonality and continuity between humans and non humans does not gainsay human specificity or, for that matter, deny the imperative to live with and alongside them as fellow natural beings. Winner of the 2010 Wildscreen Natural History Museum Environmental Award, Green left the festival audiences shaken, tearful, desperate and angry. As an independent media intervention Green may therefore do far more than, as a senior executive from National Geographic opined, 'bear witness' to avoidable and unnecessary destruction inferring that the international media markets and modes of finance, production and distribution allow for little else. At the time of writing it has not been broadcast on the major satellite channels like Discovery or Animal Planet suggesting that either its aesthetic or its politics is seen by commissioning editors as unattractive 
to viewers, commercial sponsors and potential advertisers. However, it has been sold to public broadcast channels SVT Sweden, NHK Japan, France 5, RAI Italy and Canal+ Poland, RTBF Belgium and Oasis HD Canada.

\title{
Conclusion
}

What these media texts, contexts, pedagogic and conservation interventions have in common is a recognition that human and non human animals have co-evolved and are biologically, socially and ethically interdependent. Both have needs relating to the living of their species-being but only humans can take into account, mitigate or address the needs of other creatures when capitalist development, scientific interest, amenity, corporate entertainment, resource extraction, economic benefit or habitat destruction adversely effects the lives of animals. Ted Benton (1993: 211) writes,

\begin{abstract}
Where populations of non human others are cut off by human practices from the conditions under which they are able to autonomously meet their needs and so live the life of their species, the consequences are either extinction, local or global, or some form of human intervention deliberately to sustain suitable habitat by checking the offending social practices or imposing some kind of artificial, compensatory mode of need-meeting through incorporation within human social forms. Where dependency in either mode is a consequence of human activity, there is a place for a notion of acquired responsibilities on the part of humans for the animals affected.
\end{abstract}

In exploring the public pedagogy of environmental and conservation media critical educators should elucidate, refine and promote these 'acquired responsibilities' and be mindful of the largely unrealised pedagogic capacity of new and old media to promote more sustainable practices through fashioning new modes of engaged learning and connective understanding. This requires critical environmental educators to become media researchers and even media ecologists as the media is unarguably an important element of our produced environment, our produced (human) nature and all of our futures.

\section{References}

Author 2010 


\section{Author 2011}

Apley, A. 2008. 'Giant Screen Films and Lifelong Learning'. Paper presented at the Giant Screen Cinema Association Symposium: The Greater Potential of Giant Screen Experiences- Connecting Society and Science, September 8, in Jersey City, New Jersey.

Bahk, C.M. 2011. Environmental Education Through Narrative Films: Impact of 'Medicine Man' on Attitudes Toward Forest Preservation. The Journal of Environmental Education, 42, no.1, 1-13.

Barry, A M. 2008. Science and Visual Communication. Giant Screen Cinema Association Symposium: The Greater Potential of Giant Screen ExperiencesConnecting Society and Science, September 8, in Jersey City, New Jersey.

Beattie, K. 2008. Documentary Display: reviewing nonfiction film and video. London: Wallflower Press.

Beder, S. 2006. Suiting Themselves: how corporations drive the global agenda. London: Earthscan.

Benton, T. 1989. Marxism and Natural Limits: an ecological critique and reconstruction. New Left Review, 178, 51-81.

Benton, T. 1993. Natural Relations: ecology, animal rights and social justice. London: Verso.

Bhaskar, R. 2008. A Realist Theory of Science. London: Verso.

Bourdieu, P. and Wacquant, L.J.D. 1992. An Invitation to Reflexive Sociology. Cambridge: Polity Press.

Bouse, D. 2000. Wildlife Films. Philadelphia: University of Pennsylvania Press.

Brockington, D., Duffy, R. and Igoe, J. (2008) Nature Unbound: Conservation, Capitalism, and the Future of Protected Areas. London, Earthscan.

Carson, R. 1999. Silent Spring. London: Penguin Books.

Carroll, N. 2003. Engaging the Moving Image. New Haven: Yale University Press.

Castree, N. 2000. Marxism and the Production of Nature. Capital and Class, 72, 536.

Castree, N. 2003. Commodifying What Nature? Progress in Human Geography, 27, no.3, 273-297.

Chris, C. 2002. All Documentary, All the Time? Television and New Media, 3, no.1, 7-23. 
Chris, C. 2006. Watching Wildlife. Minneapolis: University of Minnesota Press.

Christophers, B. 2006. Visions of Nature, Spaces of Empire: Framing natural history programming within geometries of power. Geoforum, 37, no.6, 973-985.

Colombat, A. P.1991. A Thousand Trails to Work with Deleuze. SubStance, 20, no.3, 10-23.

Cottle, S. 2004. Producing Nature(s): on the changing ecology of natural history TV. Media, Culture and Society, 26, no.1, 81-101.

Cousteau, J. and Schiefelbein, S. 2007. The Human, The Orchid and the Octopus. New York: Bloomsbury.

Deleuze, G. 1986. Cinema 1: The Movement-Image, trans. Hugh Tomlinson and Barbera Habberjam. Minneapolis: University of Minnesota Press.

Deleuze, G. 1989. Cinema 2: The Time-Image, trans. Hugh Tomlinson and Robert Galeta. London: Athlone Press.

Deleuze, G. 1995. Negotiations, 1972-1990. New York: Columbia University Press.

Deleuze, G, and Guattari, F. 2004. A Thousand Plateaus. London: Continuum.

Denzin, N.K. 2003. Performance Ethnography: critical pedagogy and the politics of culture. Thousand Oaks: Sage.

Duffy, R. and Moore, L. 2010. Neoliberalizing Nature? Elephants as imperfect commodities. Antipode, 42, no.3, 742-766.

Duffy, R. 2010. Nature Crime: how we're getting conservation wrong. New Haven: Yale University Press.

Ellsworth, E. 2005. Places of Learning: media, architecture and pedagogy. New York: Routledge.

Foale, S. and Macintyre, M. 2005. Green Fantasies: Photographic representations of biodiversity and ecotourism in the Western Pacific. Journal of Political Ecology, $12,1-22$.

Fortner, R.W. and Lyon, A. E. 1985. Effects of a Cousteau Television Special on Viewer Knowledge and Attitudes. Journal of Environmental Education, 16, no.3, 1220.

Foster, J. B., Clark, B. and York, R. 2010. The Ecological Rift: capitalism's war on the Earth. New York: Monthly Review Press.

Gadgil, M. and Guha, R. 1995. Ecology and Equity. New Delhi: Oxford University Press. 
Giroux, H. A. 2000. Public Pdagogy as Cultural Politics: Stuart Hall and the 'Crisis' of Culture. Cultural Studies, 4, no.2, 341-360.

Giroux, H. A. 2001. The Mouse that Roared: Disney and the End of Innocence. Maryland: Rowman and Littlefield.

Giroux, H. A. 2004. Public Pedagogy and the Politics of Neo-liberalism: making the political more pedagogical. Policy Futures in Education, 2, no. 3-4, 494-503.

Greenpeace. 2007. How the Palm Oil Industry is Cooking the Climate. Amsterdam: Greenpeace International.

http://www.greenpeace.org/international/Global/international/planet-

2/report/2007/11/cooking-the-climate-full.pdf

Griffiths, A. 2008. Shivers Down Your Spine: Cinema, Museums, and the Immersive View. New York: Columbia University Press.

Grodal, T. 2006 The PECMA Flow: A General Model of Visual Aesthetics. Film Studies, Issue 8, pp1-11.

Grodal, T. 2009. Embodied Visions: evolution, emotion, culture and film. New York: Oxford University Press.

Harvey, D. 1996. Justice, Nature and the Geography of Difference. Oxford: Blackwell.

Harvey, D. 2006. The Limits to Capital. London: Verso.

Heise, U.K. .2003. 'From extinction to electronics: Dead frogs, live dinosaurs, and electric sheep'. In Zootologies: the question of the animal, ed Wolfe C. 69-82.

Minneapolis: University of Minnesota Press

Herzog, A. 2000. Images of Thought and Acts of Creation: Deleuze, Bergson, and the Question of Cinema. Invisible Culture: an electronic journal for visual studies. Issue 3. http://www.rochester.edu/in visible culture/issue3/herzog.htm

Holbert, R. L., Kwak, N. \& Shah, D. V. 2003. Environmental Concern, Patterns of Television Viewing, and Pro-Environmental Behaviors: Integrating Models of Media Consumption and Effects. Journal of Broadcasting \& Electronic Media, 47, no. 2, 177-196.

Igoe, J., Neves, K. \& Brockington, D. 2010. A Spectacular Eco-Tour around the Historic Bloc: Theorising the Convergence of Biodiversity Conservation and Capitalist Expansion. Antipode, 42 no.3, 486-512.

Kompridis, N. 2005. Disclosing Possibility: The Past and Future of Critical Theory. International Journal of Philosophical Studies, 13, no.3, 325-351. 
Lombard, M. \& Ditton, T. (1997) At the Heart of It All: the Concept of Presence. Journal of Computer-Mediated Communication, 3, no. 2.

http://jcmc.indiana.edu/vol3/issue2/lombard.html

Lum, C.M.K. ed. 2006.Perspectives on Culture, Technology and Communication: the Media Ecology Tradition. Cresskill NJ: Hampton Press.

Mander, J. 2002. Four Arguments for the Elimination of Television. New York: Perennial.

McGavin, G. 2010. personal communication.

McLuhan, M. 1964. Understanding Media: the extensions of Man. Cambridge Mass.: MIT Press.

Mitchell, W.J.T. 2002. Showing Seeing. Journal of Visual Culture, 1, no.2, 165-181.

Munster, A. 2006. Materializing New Media Embodiment in Information Aesthetics. Dartmouth: University Press of New England.

Nicholls, S. (2010) personal communcation

Norgaard, K.M. 2006. "People Want to Protect Themselves a Little Bit": Emotions, Denial, and Social Movement Nonparticipation. Sociological Inquiry, 76, no.3, 372396.

Palmer, C. (2010) personal communication

Postman, Neil. 1986. Amusing Ourselves to Death. London: Methuen.

Recuber, T. 2007. Immersion Cinema: The Rationalization and Reenchantment of Cinematic Space. Space and Culture, 10, no.3, 315-330.

Rodowick, D.N. ed 2009. Afterimages of Gilles Deleuze's Film Philosophy. Minneapolis: University of Minnesota Press.

Sassen, S. 2010. A Savage Sorting of Winners and Losers: contemporary versions of primitive accumulation. Globalizations, 7, no.1, 23-50.

Savage, G. C. 2009. "Problematizing 'Public Pedagogy' in Educational Research" in eds Sandlin, J.A., Schultz, B.D. \& Burdick, J. Handbook of Public Pedagogy: Education and Learning Beyond Schooling. New York: Routledge.

Sayer, A. 2000. Realism and Social Science. London: Sage.

Shaheen, J.G. 1987. The Documentary Art: "The Undersea World of Jacques Cousteau". Journal of Popular Culture, 21, No.1, 93-101.

Smith, N. 2010. Uneven Development: nature, capital and the production of space. London: Verso. 
Sobchack, V. 1992. The Address of the Eye:a phenomenology of film experience. Princeton NJ: Princeton University Press.

Sobchack, V. 2004. Carnal Thoughts: embodiment and moving image culture. Berkeley: University of California Press.

Soper, K. 1995. What is Nature? Oxford: Blackwell.

Tisdell, E.J. \& Thompson, P.M. 2007. 'Seeing from a different angle': the role of pop culture in teaching for diversity and critical media literacy in adult education. International Journal of Lifelong Education, 26, no.6, 651-673.

Wallington, G. 2010. personal communication.

Watson, G. 2011 Field Birding and Digital Objects. Environmental Education Research, , no., .

Winn, M. 2002. The Plug-in Drug. New York: Penguin Books.

Wright, R.R. \& Sandlin, J.A. 2009. Popular Culture, public pedagogy and perspective transformation: The Avengers and adult learning in living rooms. International Journal of Lifelong Education, 28, no.4, 533-551.

Zerubavel, E. 1997. Social Mindscapes: An Invitation to Cognitive Sociology. Cambridge MA: Harvard University Press.

\footnotetext{
${ }^{\mathrm{i}}$ The quotations are from an AHRC ethnographic research project, Spectacular Environmentalism.
} 